\title{
3G-based Mobile Commerce Value Chain
}

\author{
Ting $\mathrm{Li}^{1}$, Yong $\mathrm{Liu}^{2}$ \\ 1 Department of Information Management, Huazhong Normal \\ University, Wuhan, 430079, China \\ lostway@126.com \\ 2 Department of Information Management, Huazhong Normal \\ University, Wuhan, 430079, China
}

\begin{abstract}
In recent years, due to the rapid evolution of mobile communication technologies, e-commerce has been combined with the mobile communication equipment, and a new paradigm of business - mobile commerce has appeared in business field. Nowadays, the development of 3G-related technologies further pushed the popularity of m-commerce. This paper attempts to categorize the participants in the $3 \mathrm{G}$-based m-commerce value chain in $\mathrm{B} 2 \mathrm{C}$ market and discusses its nature as well. It established a value chain in 3Gbased B2C mobile market. This study can provide some fresh insight to 3Gbased mobile market and help the participants in the value chain to understand better on how the value on the mobile market is delivered, which can offer them some ideas on how to make the value to be delivered efficiently on the value chain.
\end{abstract}

\section{Introduction}

The prevalence of the Internet has greatly changed our lives, which revolutionizes the traditional way of conducting business and gives birth to the electronic commerce (e-commerce). In recent years, due to the rapid evolution of mobile communication technologies, e-commerce has been combined with the mobile communication equipment, and a new paradigm of business - mobile commerce (mcommerce) has appeared in business field. Nowadays, the development of the thirdgeneration $(3 \mathrm{G})$-related technologies further pushed the popularity of $\mathrm{m}$-commerce, which overcomes the bandwidth limitation in traditional $2 \mathrm{G}$-based $\mathrm{m}$-commerce.

In China m-commerce has been developed in the past several years. In fact $\mathrm{m}$ commerce has a good foundation in China. According to the news released by China State Research Center, there are about 420 million mobile phone users in China by May 2006, and Deng (2006), the minister of the research center, forecasts that there

Please use the following format when citing this chapter:

Li, T., Liu, Y., 2007, in IFIP International Federation for Information Processing, Volume 251, Integration and Innovation Orient to E-Socicty Volume 1. Wang, W. (Eds), (Boston: Springer), pp. 484-490. 
will be about US $\$ 760$ billion investments on $3 \mathrm{G}$ within the coming 5 years in China. He also predicts that after the full deployment of $3 \mathrm{G}$ in China, $3 \mathrm{G}$ users in China will reach 6.2 million in the first year and the number of $3 \mathrm{G}$ users in China will rise to 200 million in five years [1]. Obviously, there will be a huge market in the $3 \mathrm{G}$ related industries in China.

Some researches have been conducted in $3 \mathrm{G} \mathrm{m}$-commerce. But few studies have been done on the value chain in $3 \mathrm{G}$ m-commerce. In fact 3G-based value chain in $\mathrm{m}$ commerce is quite different from some other traditional value chains. First, mcommerce value chain is essentially the aggregation of the mobile communication value chain and the Internet value chain [2]. The business models and value chains of the above two industries may not completely be applied to m-commerce [3]. Second, as Kim (2007) states that most adopters and users of traditional technologies are employees in an organizational setting. They use the technology for work purposes, and the cost of mandatory adoption and usage is covered by organizations. In contrast, adopters and users of new information and communication technology, such as mobile Internet, are individuals who use it for personal purposes and the cost is normally covered by themselves [4]. Individuals become the main customers in mcommerce market, and the value chain based on business-to-customer (B2C) business model will inevitably become the mainstream in 3G-based m-commerce.

This paper attempts to categorize the participants in the 3G-based m-commerce value chain in $\mathrm{B} 2 \mathrm{C}$ market and discusses its nature as well. It establishes a value chain in 3G-based B2C mobile market. This study can provide some fresh insight to $3 \mathrm{G}$-based mobile market and help the participants in the value chain to understand better on how the value on the mobile market is delivered, which can offer them some ideas on how to make the value to be delivered efficiently on the value chain.

\section{Literature Review}

With the rapid development of mobile technology and application of mobile equipment in business, m-commerce has achieved success in some countries and become the focus in research in recent years. Though there are some researches on the value chain in $3 \mathrm{G}$-based $\mathrm{m}$-commerce, there is no agreement on the categories and the roles of the participants in the value chain in m-commerce [3]. Siau et al. (2001) state that the process of linking additional values to the end users primarily include customer, bank, mobile network operator, and other possible members [5]. Tsalgatidou and Veijalainen (2000) point out that the value chain make the participants to be involved in the activities along the value chain, which alters the value system in the traditional mobile communication industry, and undoubtedly forms new values for consumers [6].

Barnes (2002) provides a basic model of m-commerce value chain, which consists of six core processes in two main areas: content, infrastructure and services. The area of content contain three core processes: content creation, content packaging and market making, and in the area of infrastructure and services there are three core processes as well: mobile transport, mobile services and delivery support, mobile interface and applications, and the importance of the two main areas are equal. [7]. 
Buellingen and Woerter (2004) state that broadband mobile transmission with universal mobile telecommunications system (UMTS) will lead to some essential alteration of mobile communication visible in the expansion of the mobile value chain and build an extended mobile communication value chain. In the value chain, they generalize six key factors: nets and infrastructure, interface software, customer acquisition, transmission, content and portals, customer relation management and billing. They point out that new m-commerce value chain will increase the power of the mobile network operators by reason of controlling portal serves, which guides users and reduces searching efforts in search activities through presetting [8].

Ying and Ching (2006) categorize the participants on the 3G-based mobile commerce value chain into eleven roles: technology platform vendors, infrastructure and mobile equipment vendors, application platform vendors, application developers, content developers, content aggregators, mobile portal providers, $3 \mathrm{G}$ mobile network operators, mobile service providers, mobile equipment retailers and customers [3]. All these different roles are closely linked like a circle and customers stay in the center. They stress that $3 \mathrm{G}$ mobile network operators are the core members in the $\mathrm{m}$ commerce value chain. Mobile network operators are increasingly more important, which take the functions as mediators, brokers, trustees and service providers for third parties in the value chain. The role of mobile network operators as mediators and gatekeepers is the traditional advantages in $2 \mathrm{G} \mathrm{m}$-commerce, which is natural for them to inherit these advantages in new 3G-based m-commerce. There is growing recognition of the value of contents and services in the value chain in $3 \mathrm{G}$-based mobile market. Mobile phone is with the limitation of screen size and manipulation difficulty, which demands more additional mental and physical efforts [4]. Offering attractive contents and convenient services can attract customers to adopt mcommerce.

\section{3G-based M-commerce Value Chain}

Based on the above-mentioned studies, we try to establish a new model of $3 \mathrm{G}$-based m-commerce value chain through analyzing the key players in the value chain and investigating their relationship and respective features.

The participants of $3 \mathrm{G}$-based m-commerce value chain can be generally categorized into the following 8 different roles: technology platform vendors, $3 \mathrm{G}$ mobile network operators, mobile equipment vendors, content providers, application platform vendors, mobile portal providers, customers, and online financial services providers.

\subsection{Technology platform vendors}

Technology platform vendors mainly deal with the operation and maintenance of backbone network, base stations, the infrastructure and facilitating the transmission of mobile data between mobile users and application service providers [9], and providing operating systems for smart phones and micro-browsers, which are necessary to mobile Internet services, is also the task of technology platform vendors 
[6]. Technology platform vendors often charge a lot of money from patent royalty and equipment sales. For example, in China totally RMB $¥ 250$ billion has been paid abroad to the technology platform vendors in $1 \mathrm{G}$ network construction, while the amount has reached RMB $¥ 500$ billion in $2 \mathrm{G}$ network construction [1]. The huge expense on technology platform vendors is surely to raise the cost of $3 \mathrm{G}$ network. Currently in China, the TD-SCDMA has been promoted as the $3 \mathrm{G}$ standards, and Chinese enterprises own a relatively high intellectual property rights in the TDSCDMA standards, which might lower the cost in $3 \mathrm{G}$ network instruction in China.

\subsection{G mobile network operators}

3G mobile network operators play a key role in m-commerce value chain. No matter the general consumers or enterprise users, they need to access the bridge provided by $3 \mathrm{G}$ mobile network operators to enjoy or provide mobile services. Generally speaking, mobile network operators refer to telecommunication corporations [10]. In China $3 \mathrm{G}$ mobile network operators are mainly based on the original $2 \mathrm{G}$ mobile network operators, including China Mobile, China Telecom, China Unicom and China Netcom. As mobile network providers are primarily responsible for providing wireless network to ensure network quality of service and mobile location infrastructure, such as global system for mobile communications (GSM) roaming services and connection of different mobile networks.

\subsection{Mobile equipment vendors}

Mobile equipment vendors design and manufacture all kinds of infrastructure required for building mobile communication networks, and other devices which support Wireless Application Protocol (WAP), General Packet Radio Service (GPRS), 3G, and other communication technologies. They play important roles in promoting innovations in technology in mobile industry [10, 11]. In China, according to Byna Telecom Consulting Company's analysis, the market share has undergone a significant change in the present experimental network: Ericsson, ZTE, Huawei, Shanghai Bell and Alcatel are at first echelon, and the domestic manufacturers, such as ZTE and Huawei, are expected to take $40 \%$ to $50 \%$ share of the $3 \mathrm{G}$ mobile equipment market [12].

\subsection{Content Providers}

Content providers include content developers and content aggregators. Content developers provide, design, or produce various kinds of products or services necessary to all consumers [10]. When mobile devices become ubiquitous, content developers have to provide various kinds of content services to attract more consumers to use $\mathrm{m}$-commerce model [11]. Content aggregators aggregate, integrate, re-package or distribute products or services to consumers, such as games, news and financial messages. 3G-based content providers have relatively high status in the whole value chain than in traditional $2 \mathrm{G}$. When the content providers supply large 
volume of data and diversified information services, customers can make a comparison between $2 \mathrm{G}$ and $3 \mathrm{G}$ mobile services, and the advantages of high transmission rate in $3 \mathrm{G}$ market can be standout.

\subsection{Application platform vendors}

Application platform vendors are the middleware providers on the value chain, who are responsible for providing pre-built components, including wireless middleware and application middleware $[10,13]$. Based on the content provided by content providers, application platform vendors develop the commercial use on existing mobile networks, such as the mass-broadcast robot based on short messaging service (SMS), and real-time traffic information service based on global positioning system (GPS).

\subsection{Mobile portal providers}

Mobile portal providers provide the gateway to access wireless networks and the first window to enjoy $3 \mathrm{G}$ information services. Aggregating services and information content of all kinds of properties, information index, search tools, and related services are provided to assist users in searching for desired information by mobile portal providers as well [9]. At present, mobile portals are generally provided by the combination of mobile operators (such as the BBC), application developers (such as Air Flash) and the client providers (such as Nokia, Microsoft).

\subsection{Customers}

Generally speaking, customers can be divided into individual consumers or enterprise users, which are both important in traditional commerce. In $3 \mathrm{G}$-based mcommerce market, individuals become the main customers, and $\mathrm{B} 2 \mathrm{C}$ business model becomes the mainstream in 3G-based m-commerce.

\subsection{Online financial services providers}

Online financial services providers include commercial banks, the third-party mobile payment platform companies, and safety certificating agencies. Though online financial services providers have a much less influence on the value chain, they ensure the value flow to go smoothly and safely. Their importance can not be ignored in the mobile value chain.

The 8 different roles on the 3G-based m-commerce value chain are illustrated in Figure 1. 3G mobile network operators, content providers, application platform vendors, mobile portal providers and customers are the frontline participants and main value-creators in the value chain. Content Providers, which differentiate the $3 \mathrm{G}$ from $2 \mathrm{G}$, are the main source of the value in the value chain. When customers begin to use 3G-based products or services offered by content providers, the 3G-based mcommerce value chain begin to operate and make profits. Application platform 
vendors develop new software based on the contents provided by content providers. $3 \mathrm{G}$ mobile network operators provide the customers with value-added services, which are also based on the content providers. In this process, the amount of value rises when value flows from content providers to application platform vendors and $3 \mathrm{G}$ mobile network operators. Mobile portal providers offer $3 \mathrm{G}$ users opportunities to know and apply 3G-based services. Through mobile portal providers, 3G users can browse and retrieval different services in detail. Finally, customers enjoy the services and pay for their consumption - that is the end of value flow.

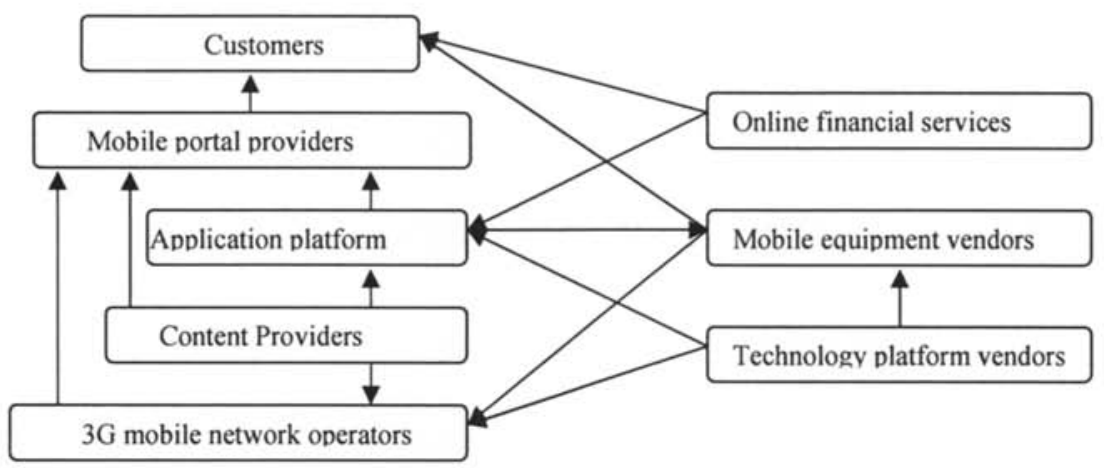

Figure 1. The 3G-based Mobile Commerce Value Chain

Technology platform vendors, mobile equipment vendors and online financial services are the main supporters in 3G-based $\mathrm{m}$-commerce value chain. Though they do not create or increase the value in the value chain, they are indispensable in the value chain. Technology platform vendors provide the technology standards in the value chain. Mobile equipment vendors supply $3 \mathrm{G}$-related equipments to different participants and aggregate new foundations and software developed by application platform vendors. And online financial services ensure all the participants to get their money or services from other participants in the value chain.

\section{Discussion and conclusion}

Based on the literature review of various studies on m-commerce value chain, a new model of 3G-based m-commerce value chain has been proposed in this study, and the 8 different participants are discussed on their roles and features in the value chain. The model illustrates the relationship of the 8 different participants in value chain. In the transforming process from traditional 2G-based m-commerce to 3G-based mcommerce, the relationships between participants in the value chain are getting more and more complex. Good cooperation is the base for the success of 3G-based mcommerce.

In 3G-based m-commerce value chain, $3 \mathrm{G}$ mobile network operators still hold a core position, which provide the basic networks for the entire value chain, while technology platform vendors, mobile equipment vendors and online financial 
services work as supporters to ensure the security and privacy of entire system. Different from traditional $2 \mathrm{G}$ m-commerce which are driven by technologies, $3 \mathrm{G} \mathrm{M}$ commerce is driven by contents and services. Though technologies are of great importance to the construction of $3 \mathrm{G} \mathrm{m}$-commerce value chain and to the ease of use for customers, the development of content and new services is critical for the success of $3 \mathrm{G}$-based $\mathrm{m}$-commerce.

Researchers and practitioners remains considering further work on integration between content supporters and technology supporters in 3G-based m-commerce value chain. There is the scope for further work on developing attractive contents or services to customers with proper technology.

\section{References}

1. Shoupen Deng, The Speech in TD-SCDMA Economical Annual Meeting 2006, http://www.ce.cn/cysc/communications/rw/200602/22/t20060222_6164863.shtm I

2. C.F. Maitland, J.M. Bauer, and R. Westerveld, The European Market for Mobile Data: Evolving Value Chains and Industry Structures, Telecommunications Policy 26(9-10), 485-504(2002).

3. FengKuo Ying, and WenYu Ching, 3G Telecommunication Operator's Challenges and Roles: A Perspective of Mobile Commerce Value Chain, Technovation 26, 1347-1356 (2006).

4. Hee-Woong Kim, H.C. Chan, and S. Gupta, Value-based Adoption of Mobile Internet, Decision Support Systems 43, 111-126 (2007).

5. K. Siau, E.P. Lim, and Z. Shen, Mobile Commerce: Promises, Challenges, and Research Agenda, Journal of Database Management 12 (3), 4-13 (2001).

6. A. Tsalgatidou, J. Veijalainen, Mobile Electronic Commerce: Emerging Issues. In: Proceedings of EC-WEB 2000 lst International Conference on E-Commerce and Web Technologies London, Greenwich, UK, September, 477-486 (2000).

7. S. J. Barnes, The mobile commerce value chain: analysis and future developments, International Journal of Information Management 22, 91-108(2002).

8. F. Buellingen, and M. Woerter, Development Perspectives, Firm Strategies and Applications in Mobile Commerce, Journal of Business Research 57, 1402-1408 (2004).

9. N. Barnett, S. Hodges, M.J. Wilshire, M-commerce: An Operator's Manual. McKinsey Quarterly 3, 162-173 (2000)

10. F. Müller-Veerse, Mobile Commerce Report. Durlacher Research Ltd, http://www.durlacher.com/downloads/mcomreport.pdf.

11. H.K. Sabat, The Evolving Mobile Wireless Value Chain and Market Structure, Telecommunications Policy 26 (9-10), 505-535 (2002).

12. Zhangkun $\mathrm{Yu}$, Equipment manufacturers will account for $40 \%-50 \%$ of the domestic $3 \mathrm{G}$ market share, http://www.byna.cn/Html/view/20065/9/200605090002995.html

13. R. Kalakota, and M. Robinson, M-Business: The Race to Mobility (McGraw-Hill, New 